\author{
П. М. МИХАЙЛЕНКО, Ю. М. СКАЛЕЦЬКИЙ, С. В. ПРОТАС
}

\title{
ІНФОРМАЦІЙНІ ТА ІНСТИТУЦІЙНІ РЕСУРСИ ФОРМУВАННЯ ДЕРЖАВНОї ПОЛІТИКИ У СФЕРІ ОХОРОНИ ЗДОРОВ'Я В УКРАЇНІ
}

\author{
ДУ «Інститут громадського здоров'я ім. О. М. Марзєєва НАМН України», м. Київ, Україна
}

\begin{abstract}
Мета: визначити наявні інституційні та інформаційні ресурси для забезпечення інсормаційно-аналітичної підтримки фрормування і реалізації державної політики у сфері охорони здоров'я в Україні та шляхи інтенсифрікації їх взаємодії.

Матеріали і методи. Міжнародні та національні нормативно-правові акти, аналітичні та керівні документи Європейського регіонального бюро ВОО3, звітно-аналітичні доповіді центральних органів виконавчої влади, незалежних експертів, статутні документи інституцій, задіяних у створенні та обробці наукових і фактичних даних, зборі та аналізі статистичних даних у сорері охорони здоров'я, наукові публікації. Застосовано бібліосемантичний метод дослідження.

Результати. Проаналізовано керівні та аналітичні документи Європейського регіонального бюро ВООЗ щодо інсрормаційно-аналітичної підтримки прийняття політичних рішень; досліджено інституційні ресурси і джерела релевантної інформації для забезпечення прийняття рішень у формуванні та реалізації державної політики. Зокрема, зазначається, що державні установи НАМН України, як розпорядник наукових та фактичних даних у ссері охорони здоров'я, $є$ головним інституційним ресурсом інформаційно-аналітичного супроводу прийняття рішень і мають виконувати координуючу функцію у його забезпеченні.

Висновки. Спрямовані на шляхи забезпечення ефрективної взаємодії усіх зацікавлених сторін, що $є$ розпорядниками релевантної інформації, забезпечення регулярного узагальнення і оприлюднення інформації у ссрері охорони здоров'я та презентації результатів інфрормаційно-аналітичної роботи як органам, що фрормують політику, так і широким верствам громадськості.
\end{abstract}

КЛЮЧОВІ СЛОВА: формування та реалізація політики; використання даних наукових досліджень при формуванні політики; наукові та фактичні дані; система охорони здоров'я; інституційні ресурси для прийняття рішень.

На сьогодні в Україні наявні ознаки демографрічної кризи, однією з причин якої, крім соціальноекономічних, $€$ погіршення здоров'я населення $[1,14]$. Це явище вимагає поглибленого аналізу практики формування та реалізації державної політики у сорері охорони здоров'я (О3) у загальній системі державних пріоритетів.

У країнах-членах Європейського регіону ВООЗ відбувається зміна парадигми в галузі О3: акценти з проблем смертності та захворюваності зміщуються на завдання покращення здоров'я і підвищення рівня благополуччя. За таких умов Міністерство охорони здоров'я 3 центрального органу державної влади у сорері надання медичних послуг трансформується у центр координації фрункцій громадського здоров'я інших органів державної влади, а політика у ссрері охорони здоров'я з галузевої розширюється до загальнодержавного рівня зі значним зростанням фрункцій стратегування та моніторингу. Для того, щоб інформація сорери О3 повноцінно відображала ці зміни, визнано доцільним приділяти більше уваги, окрім кількісних, суб'єктивним та якісним даним [7]. Розробка адекватних показників і визначення належних джерел даних для таких нових категорій, як, наприклад, благополуччя населення, пов'язані з методологічними труднощами, оскільки ці процеси потребують часу для вироб- лення й уніфікації суб'єктивних оцінок і якісних показників [8].

У системі традиційного моніторингу «Здоров'я - 2020: основи Європейської політики в підтримку дій держави та суспільства в інтересах здоров'я і благополуччя» вищезазначені питання не є звичними [5]. Включені також й інші показники, які раніше не були предметом рутинного спостереження, такі, наприклад, як життєстійкість і розширення прав та можливостей громади. Необхідні детальні розробки для їх практичної інкорпорації в механізми моніторинга і оцінювання політики. Особливо важливо адаптувати ці нові європейські підходи з огляду на активні процеси децентралізації в Україні та формування об'єднаних територіальних громад з розширеними повноваженнями, зокрема у сфері медичного забезпечення населення [10, 13].

Як інновації розглядаються нетрадиційні джерела даних, такі, як онлайнові соціальні мережі, облікові відомості мобільного телефонного зв'язку та електронні записи медичної реєстрації, які можуть додати новий фрактичний матеріал до традиційної статистики ОЗ. Зазначимо побіжно, що впроваджувана на сьогодні в Україні система «Електронне здоров'я» дозволить змінити формат носіїв інформації та полегшити облік та обмін даними. Проте для прийняття рішень і формування політики кожного разу необхідна 
експертна аналітична обробка фрактичних та наукових даних.

Мета роботи: визначити наявні інституційні та інформаційні ресурси для забезпечення інформаційно-аналітичної підтримки фрормування і реалізації державної політики у сорері охорони здоров'я в Україні та шляхи інтенсифрікації їх взаємодії.

Матеріали і методи. Міжнародні та національні нормативно-правові акти, аналітичні та керівні документи Європейського регіонального бюро ВОО3, звітно-аналітичні доповіді центральних органів виконавчої влади, незалежних експертів, статутні документи інституцій, задіяних у створенні та обробці наукових і фрактичних даних, зборі та аналізі статистичних даних у сорері охорони здоров'я, наукові публікації. Застосовано бібліосемантичний метод дослідження.

Результати дослідження та їх обговорення. Однією із ключових проблем при фрормуванні та впровадженні державної політики у країнах Європейського регіону ВООЗ визнано недостатність інфрормації та наукової підтримки прийняття рішень. У Доповіді про стан охорони здоров'я в Європі (2015 р.) «Цільові орієнтири і більш широкі перспективи - нові рубежі в роботі з фактичними даними» визначено нові тренди у сорері О3 [2]. Правильність обраного вектора підтверджено у черговій Доповіді про стан здоров'я в Європі (2018 р.), яка має назву «Більше, ніж просто цифри: фрактичні дані для всіх» [3]. Теза від 2015 р. про те, що для формування достовірних уявлень щодо стану справ у сфері ОЗ недостатньо мати лише фракти і цифри - необхідні нові фрорми фрактичних даних - отримала розвиток та деталізацію. Як вже зазначалося, нова тенденція полягає у використанні не лише статистичних, а й інших типів даних, які дозволяють вийти за рамки цифр і врахувати суб'єктивний досвід людей. Країни Європейського регіону ВООЗ першими почали активно застосовувати цей новий, цілісний і більш ефективний спосіб оцінки впливу заходів політики на здоров'я та благополуччя людей.

Інформаційні ресурси та вихідні дані для розробки та реалізації політики

Ще у 2003 р. Європейське регіональне бюро ВОО3 (ЄРБ ВОО3) на пропозицію Європейського консультативного комітету з наукових даних у галузі охорони здоров'я почало використовувати наступне широке визначення фрактичних даних, до яких належать дані досліджень і контекстуальна інформація, що виділяється з інших видів знань: «результати наукових досліджень та інші знання, які можуть стати корисною основою для прийняття рішень в галузі громадського здоров'я і медико-санітарної допомоги» [18]. На сьогодні ЄРБ ВООЗ доопрацьовує це вихідне визначення, дотримуючись принципу «фактичні дані сприяють прийняттю рішень, але не зумовлюють їх».

Саме такий підхід до роботи 3 фрактичними даними лежить в основі першого Плану дій на підтримку використання фрактичних даних, інформації і наукових досліджень при виробленні політики у Європейському регіоні ВОО3 [9].
3 жовтня 2012 р. у Європейському регіоні ВОО3 почала діяти Мережа 3 питань використання наукових даних при фрормуванні політики EVIPNet-Європа (EVIPNet - Evidence-Informed Policy Network) [21]. Мережа вирішує одне із стратегічних завдань ЄРБ ВООЗ - забезпечення держав-членів інструментами і потенціалом для зміцнення зв'язку між даними наукових досліджень та політикою у процесі прийняття рішень. Для досягнення цієї мети EVIPNet-Європа пропонує таку послідовність дій: визначення пріоритетних питань для розробки політики; збір наукових даних; узагальнення наукових і фрактичних даних; підготовка аналітичних оглядів для фрормування політики; скликання нарадчого діалогу; підтримка фрормування варіанта політики і його реалізації; моніторинг і оцінювання.

Визначення пріоритетних питань для розробки політики

Складнощі реформування галузі, зумовлені, на нашу думку, відсутністю системного аналізу причин невідповідності української системи охорони здоров'я (СО3) суспільним очікуванням. Прийняття Цілей сталого розвитку до 2030 р. надає унікальну можливість країнам для оновлення зобов'язань стосовно здоров'я і благополуччя, залучення зацікавлених сторін і громадян до створення механізмів підзвітності, що передбачає аналіз значних масивів інфрормації. Цілі сталого розвитку України на період до 2030 р. $€$ орієнтиром для розроблення прогнозних і програмних документів, нормативно-правових актів 3 метою забезпечення збалансованості економічного, соціального та екологічного вимірів сталого розвитку України, рекомендовано також враховувати їх під час визначення напрямів наукових досліджень [15].

Оцінюючи 3 цих позицій пріоритети реформування національної СO3, потрібно враховувати їх концептуальну переорієнтацію, що відповідає прийнятим Україною зобов'язанням згідно з Угодою про асоціацію між Україною, з однієї сторони, та Європейським Союзом, Європейським співтовариством з атомної енергії і їхніми державамичленами, 3 іншої сторони. Концепція розвитку системи громадського здоров'я в Україні визначає, що основними цілями медичних реформ мають бути фрормування та реалізація ефективної державної політики в умовах активної децентралізації. Концепція реформування місцевого самоврядування та територіальної організації влади в Україні [11] і План заходів з реалізації нового етапу реорормування місцевого самоврядування та територіальної організації влади в Україні на 2019-2021 рр. [10] передбачають покладення повноважень щодо забезпечення санітарного та епідемічного благополуччя населення на органи місцевого самоврядування. Оприлюднено проект Закону України «Про систему громадського здоров'я» (від 22.09.2020 р. № 4142), який належить до пріоритетних у реформуванні системи ОЗ України і, серед іншого, передбачає можливість реалізації оперативних функцій гро- 
мадського здоров'я на підставі відповідних рішень органів місцевого самоврядування.

Отже, визначення пріоритетів політики вже на початковому етапі передбачає адекватний аналіз поточного стану справ, моніторинг і оцінювання впровадження із забезпеченням діалогу усіх зацікавлених сторін, включаючи інститути громадянського суспільства та населення місцевих територіальних громад.

Інформаційні ресурси на основі узагальнених наукових і фактичних даних

Достовірна і своєчасна інфрормація 3 моніторингу ситуації, оцінювання дій та фракторів, що впливають на стан цієї ситуації, $€$ основою не лише для стратегічного планування, а й для оперативного реагування на різноманітні, зокрема вищезазначені, виклики. Відповідно, основа для оцінювання закладається при стратегічному плануванні. У цілому більшість документів, що приймаються законодавчою та/або виконавчою владою, мають індикатори для оцінювання їх виконання. Окремі документи (плани та звіти) базуються на кінцевому оцінюванні попереднього етапу впровадження документа. Проте, на нашу думку, єдиним інтегральним показником ефективності діяльності центральних органів виконавчої влади у сфері О3 є стан здоров'я громадян України. Тому питання розробки і використання національних індикаторів/критеріїв для його оцінювання набуває надзвичайної ваги. Це завдання має вирішувати належне інституційне та організаційно-методичне забезпечення збору та узагальнення фрактичних та наукових даних для підготовки аналітичних оглядів, як це рекомендує ЄРБ ВООЗ [7].

Україна є членом EVIPNet-Європа 32013 р. 17-19 жовтня 2018 р. у Києві відбулася зустріч партнерів з багатьох країн, на якій обговорювали широке коло питань і, зокрема, короткострокове планування діяльності в Україні [20]. На нашу думку, є доцільним проведення навчання з підготовки аналітичних документів для усіх зацікавлених сторін з огляду на потребу вдосконалення процесу збору, опрацювання фрактичних і наукових даних за актуальними напрямами відповідно до вимог сьогодення та інституційної спроможності національної СОЗ. Таким чином, за наявності досвіду та інструментарію з підготовки інформаційно-аналітичних матеріалів $з$ питань ОЗ країн Європейського регіону ВООЗ нам потрібно визначатися, який саме формат та індикатори необхідно використовувати для вирішення наших національних проблем розвитку галузі.

Тоді постає питання щодо оприлюднення результатів такої роботи, донесення інформації до різних цільових груп - від осіб, які приймають рішення, до представників широкої громадськості. На нашу думку, у сорері О3, як і у будь-якій іншій, існує потреба постійного моніторингу ситуації, оперативного та обов'язкового періодичного (щорічного) узагальнення для вироблення пропозицій та рекомендацій щодо фрормування та впровадження галузевої політики.
Галузеві доповіді та аналітичні огляди в Україні

В Україні практика підготовки щорічних доповідей щодо розвитку окремих галузей запроваджувалася 31992 р. відповідно до спеціальних урядових рішень. Доповіді стосуються суспільно чутливих сорер діяльності, широких верств населення і готуються міністерствами та/або підпорядкованими їм науково-дослідними установами та $\epsilon$, по суті, звітом органу з інформаційними матеріалами щодо становища галузі. Такі видання містять як дані власного моніторингу, так і посилання на дані Державної служби статистики України, які наводять у динаміці та аналізують або описують. У сорері ОЗ щорічну доповідь про стан здоров'я населення, санітарно-епідемічну ситуацію та результати діяльності системи охорони здоров'я України [17] готував Український інститут стратегічних досліджень МO3 України на виконання пункту 6 Указу Президента № 1694/2005 (редакція від 25.09.2011р.) «Про невідкладні заходи щодо реоормування системи охорони здоров'я населення». Цим Указом Кабінетові Міністрів України серед іншого доручено «забезпечити реалізацію заходів щодо підготовки та подання Президентові України щорічної доповіді про стан здоров'я населення України, санітарно-епідемічну ситуацію». Від початку оптимізації державних органів виконання цього доручення перебуває у невизначеному стані.

Первинні дані у сорері ОЗ збирає Державний заклад «Центр медичної статистики Міністерства охорони здоров'я України», який $€$ головною установою, що здійснює координацію діяльності територіальних інформаційно-аналітичних центрів медичної статистики та лікувально-профрілактичних закладів щодо збору, обробки та аналізу статистичної інформації. Наведені на офріційному сайті дані з усіх областей охоплюють практично всі характеристики стану здоров'я населення у розрізі за нозологіями, віком тощо та важливі аспекти функціонування системи охорони здоров'я - $є$ відкритими і загальнодоступними для спеціалістів і пересічних громадян. Крім того, Державна служба статистики України щороку видає тематичний збірник «Заклади охорони здоров'я та захворюваність населення України» [4]. Проте, для того, щоб стати обґрунтуванням певних рішень у площині фрормування політики, вони мають бути проаналізовані, узагальнені та доведені до інституцій та осіб, які приймають рішення, у сталому та практично спрямованому форматі.

Вже четвертий рік поспіль проводять дослідження «Індекс здоров'я. Україна» [8]. Цікаво, що предметом дослідження $€$ нові нетрадиційні якісні показники - самооцінювання власного здоров'я дорослим населенням та досвід пацієнтів у разі захворювання, задоволеність медичною допомогою, ставлення до реформи системи охорони здоров'я, здорової поведінки й досвіду звернень і витрат на медичну допомогу, 
профрілактичні заходи, до яких вдаються в Україні тощо. Важливо, що це дослідження триває 3 2016 р. дотепер із використанням ідентичної методології та інструментарію. У процесі розробки методології дослідження виконавці послуговувалися досвідом Європейського індексу споживачів охорони здоров'я [19], який дає змогу впродовж тривалого часу (з 2006 р.) порівнювати розвиток системи охорони здоров'я країн ЄС й визначати найоптимальніший шлях для подальшого розвитку.

Отже, на нашу думку, «Індекс здоров'я. Україна» у комплексі з іншими інформаційними ресурсами може використовуватися як джерело корисних даних для аналізу і підготовки рішень у ссрері О3 на національному та регіональному рівнях. Варто зазначити, що в Україні такий параметр, як самооцінка здоров'я населенням, був використаний як наскрізний показник у моніторинговому дослідженні, яке охоплювало період з 1992 до 2017 р. [12].

Важливим інституційним ресурсом позиціонується Український центр наукової медичної інформації та патентно-ліцензійної роботи МО3, який $є$ головною виробничою та науково-дослідною установою медичної галузі з проблем фрормування та використання наукової медичної інформації, науково-інорормаційних ресурсів тощо. Оскільки до основних його завдань належать: наукові дослідження 3 проблем інформатики, науковедення, соціальної гігієни та організації охорони здоров'я України; науково-інорормаційне забезпечення наукових розробок та процесів управління сорерою охорони здоров'я України, видається доцільним залучення цього ресурсу як до поточного моніторингу створення та використання медичної інфрормації, так і до підготовки та оприлюднення матеріалів за результатами такої діяльності.

I, нарешті, відповідно до пункту 2.2.4. Статуту Національної академії медичних наук України, затвердженого Загальними зборами Національної академії медичних наук України 05.04.2016 р., НАМН України «готує для органів державної влади, органів місцевого самоврядування, підприємств, установ, організацій і громадян науково-експертні доповіді, висновки, інорормаційні, аналітичні та прогнозні матеріали, пропозиції та рекомендації з проблем розвитку медичної науки та охорони здоров'я (...)». Тому, на нашу думку, саме державні установи НАМН України, як розпорядник наукових і фрактичних даних у сорері О3, $€$ головним інституційним ресурсом інфрормаційно-аналітичного супроводу прийняття рішень і мають виконувати координуючу фрункцію у його забезпеченні.

Поза межами дослідження даної статті залишився ще один дуже важливий інституційний ресурс формування та впровадження політики у сорері О3 - фрахова і широка громадськість. Це питання заслуговує окремого глибокого вивчення, оскільки шлях до успіху лежить у площині досягнення суспільного консенсусу в питаннях збереження здоров'я нації.

\section{Висновки}

1. Розбудова системи охорони здоров'я в Україні потребує залучення усіх наявних інституційних та інорормаційних ресурсів, урахування сучасних європейських трендів щодо використання наукових та фактичних даних, Цілей сталого розвитку 2030 р. та європейської політики «Здоров'я - 2020» при пріоритизації напрямів діяльності у сорері охорони здоров'я, а також активізації участі України у роботі Мережі з питань використання наукових даних при фрормуванні політики EVIPNet-Європа.

2. Для забезпечення ефективної взаємодії усіх зацікавлених сторін, закладів та установ, що $€$ розпорядниками релевантної інформації, забезпечення регулярного узагальнення і оприлюднення інфрормації у сфері охорони здоров'я необхідно організувати постійний нарадчий діалог із залученням наявних інституційних резервів та громадськості.

3. Для презентації результатів інфрормаційноаналітичної роботи як органам, що фрормують політику, так і широким верствам населення доцільно, на нашу думку, видання тематичних аналітичних оглядів за основними напрямами та оприлюднення їх на спеціалізованій онлайнплаторормі. Ця пропозиція має пройти обговорення в рамках консультативного діалогу для прийняття оптимального узгодженого рішення.

Перспективи подальших досліджень. Беручи до уваги рекомендації керівних документів ЄРБ ВОО3 та наведені висновки щодо наявних інституційних та інорормаційних ресурсів і використання наукових і фрактичних даних, видаються логічними дослідження індикаторів/критеріїв для оцінювання ефективності та своєчасного коригування державної політики у сорері ОЗ України. Важливо, щоб такі національні показники узгоджувалися 3 підсумковим документом Саміту $\mathrm{OOH}$ зі сталого розвитку «Перетворення нашого світу: порядок денний у сорері сталого розвитку до 2030 року» та іншими глобальними і європейськими ініціативами.

\section{Список літератури}

1. Голяченко А. О. Українська людність вимирає / А. О. Голяченко, В. Л. Смірнова, О. М. Левченко // Вісник соціальної гігієни та організації охорони здоров'я України. - 2016. - № 4. - С. 23-27.

2. Доклад о состоянии здравоохранения в Европе 2015. Целевые ориентиры и более широкая перспектива - новые рубежи в работе с фактическими данными. Основные положения [Электронный ресурс]. - Копенгаген : Европейское региональное бюро ВОЗ, 2015. - Режим доступа : http://www.euro.who.int/_data/assets/pdf_file/0006/293739/ European-health-report-2015-full-book-ru.pdf?ua=1. 
3. Доклад о состоянии здравоохранения в Европе 2018. Больше, чем просто цифры: фрактические данные для всех. Основные положения [Электронный ресурс]. - Копенгаген : Европейское региональное бюро ВОЗ, 2019. - Режим доступа : https://apps.who.int/iris/ bitstream/handle/10665/330083/9789289054515-rus.pdf.

4. Заклади охорони здоров'я та захворюваність населення України у 2017 році : статистичний збірник / Державна служба статистики України. - К., 2018. - 109 с.

5. Здоровье - 2020: основы европейской политики и стратегия для XXI века [Электронный ресурс]. - Копенгаген : Европейское региональное бюро ВО3, 2013. - Режим доступа : http://www.euro.who.int/ru/publications/abstracts/ health-2020-a-europeanpolicy-framework -and-strategy-for-the-21st-century.

6. Індекс здоров'я. Україна - 2019 : результати загальнонаціонального дослідження [Електронний ресурс]. - К., 2020. - Режим доступу : http://health-index.com.ua /HI_Report_2019_Preview.pdf.

7. К разработке дорожной карты по реализации Повестки дня в области устойчивого развития на период до 2030 г. в Европейском регионе ВО3. Рабочий документ. Европейский региональный комитет, 66-я сессия [Электронный ресурс]. - Копенгаген, Дания, 12-15 сентября 2016 г. - Режим доступа : https://www.euro.who.int/_data/assets/pdf_ file /0015/319110/66rs04r_SDGs_160763.pdf.

8. Мониторинг прогресса в обеспечении всеобщего охвата услугами здравоохранения на уровне отдельных стран и на глобальном уровне. Система, показатели и цели (май 2014 г.) [Электронный ресурс] / ВОЗ и Группа Всемирного банка, 2014. - Режим доступа : https://apps. who.int/iris/bitstream/handle/10665/112824/WHO_HIS_HIA_14.1_rus. pdf?sequence=8.

9. План действий в поддержку использования фрактических данных, информации и научных исследований при выработке политики в Европейском регионе [Электронный ресурс]. - Копенгаген, Дания, 12-15 сентября 2016 г. Режим доступа : https://www.euro. who.int/_data/assets/pdf_file/0005/315482/66wd12r_EIPActionPlan_160528.pdf.

10. Про затвердження Плану заходів з реалізації нового етапу реформування місцевого самоврядування та територіальної організації влади в Україні на 2019-2021 роки : Розпорядження Кабінету Міністрів України від 23.01.2019 р. № 77-p [Електронний ресурс]. - Режим доступу : https://zakon.rada.gov.ua/laws/show/77-2019$\% \mathrm{D} 1 \% 80 \#$ Text.

11. Про схвалення Концепції реформування місцевого самоврядування та територіальної організації влади в Україні : Розпорядження Кабінету Міністрів України від 1 квітня 2014 р. № 333-р [Електронний ресурс]. - Режим доступу : https://zakon.rada. gov.ua /laws/show/333-2014-\%D1\%80\#Text.

12. Соболєва Н. Самооцінка стану здоров'я населенням України / Н. Соболєва, Г. Чепурко // Соціальні виміри суспільства : зб. наук. праць. - 2017. - Вип. 9 (20). - С. 382-399.

13. Слабкий Г. О. Методологія впровадження системи громадського здоров'я на рівні об'єднаних територіальних громад / Г. О. Слабкий, І. С. Миронюк, В. В. Брич, В. Й. Білак-Лук'янчук // Вісник соціальної гігієни та організації охорони здоров'я України. - 2020. - № 3 (85). - С. 62-66.

14. Слабкий Г. О. Медико-демографічна ситуація як глобальна проблема громадського здоров'я України / Г. О. Слабкий, І. С. Миронюк, І. І. Кошеля, С. В. Дудник // Вісник соціальної гігієни та організації охорони здоров'я України. - 2019. - № 3 (81). - С. 62-72.

15. Указ Президента України від 30.09.2019 р. № 722/2019 «Про Цілі сталого розвитку України на період до 2030 року» [Електронний ресурс]. - Режим доступу : https://www.president.gov.ua/documents/7222019-29825.

16. Целевые ориентиры и индикаторы для политики Здоровье - 2020. Версия 4 [Электронный ресурс]. Копенгаген : Европейское региональное бюро ВО3, 2018. - Режим доступа : https://www.euro.who.int/_data/assets/ pdf_file/0010/378946/Targets4_RU_WEB.pdf.

17. Щорічна доповідь про стан здоров'я населення, санітарно-епідемічну ситуацію та результати діяльності системи охорони здоров'я України. 2017 рік / МОЗ України, ДУ «УІСД МОЗ України». - К., 2018. - 458 с.

18. European Advisory Committee on Health Research (EACHR). Considerations in defining evidence for public health // International Journal of Technology Assessment in Health Care. - 2003. - No. 19 (3). - P. 559-573.

19. Euro Health Consumer Index [Електронний ресурс]. - Режим доступу : http://www.healthpowerhouse.com/en/news/ euro-health-consumer-index-2015/.

20. Strengthening national health research systems (NHRS) in the WHO European Region: implementation of the European Action Plan to strengthen the use of evidence, information and research for policy-making in Ukraine (2018) [Електронний ресурс] / Summary of the national meeting on research for health, 17-19 October 2018, Kiev, Ukraine / Copenhagen. Режим доступу : https://www.euro.who.int/_data/assets/pdf_file/0004/388912/nhrs-ukr-eng.pdf.

21. Towards a culture of evidence-informed policy. Report of the 6th EVIPNet Europe multicountry meeting (2020) [Електронний ресурс] / Report of the sixth EVIPnet- Europe multicountry meeting. 3-5 September 2019, Istanbul, Turkey // Copenhagen: WHO Regional Office for Europe. - Режим доступу : https://www.euro.who.int/_data/assets/ pdf_file/0004/426784/MeeetingReport_EN_WHO_7proof.pdf.

\section{References}

1. Holyachenko, A.O., Smirnova, V.L., \& Levchenko, O.M. (2016). Ukraiinska lyudianist vymyraie [Ukrainian population is dying out]. Visnyk sotsialnoyi hihieny ta organizatsyi okhorony zdorovia Ukrainy - Bulletin of Social Hygiene and Health Protection Organization of Ukraine. 4, 23-27 [in Ukrainian].

2. Doklad o sostoyanii zdravoohraneniya v Evrope, $2015 \mathrm{~g}$. Tselevyie orientiry i bolee shirokaia perspektiva - novyie rubezhi v rabote s fakticheskimi dannymi. Osnovnyie polozheniia [The European health report 2015. Targets and beyond Reaching new frontiers in evidence]. Kopenhagen: WHO. Regional Office for Europe. - www.euro.who.int. - Retrieved 
from: http://www.euro.who.int/_data/assets/pdf_file/0006/293739/European-health-report-2015-full-book-ru.pdf?ua=1 [in Russian].

3. Doklad o sostoyanii zdravoohraneniya v Evrope 2018: Bolshe, chem prosto tsifryi: fakticheskie dannyie dlia vseh. Osnovnyie polozhennya. [The European health report 2018. More than numbers - evidence for all]. Kopenhagen: WHO. Regional Office for Europe. - apps.who.int. - Retrieved from: https://apps.who.int/iris/bitstream/hand le/10665/330083/9789289054515-rus.pdf [in Russian].

4. (2018) Zaklady okhorony zdorovia ta zahvoriuvanist naselennia Ukraiiny u 2017 rotsi. Statystychnii zbirnyk. [Health care facilities and morbidity of the population of Ukraine in 2017. Statistical collection]. - The State Statistics Service of Ukraine, 109 [in Ukrainian].

5. (2013) Zdorovie-2020 - Osnovy evropeyskoi politiki i strategiia dlia XXI veka. [ Health 2020. Foundations of European policy and strategy for the 21st sentury]. Kopenhagen: WHO. Regional Office for Europe. - www.euro.who.int. - Retrieved from: http://www.euro.who.int/ru/publications/abstracts/health-2020-a-europeanpolicy-framework -and-strategy-for-the21st-century [in Russian].

6. (2020). Indeks zdorovia. Ukraina - 2019: Rezultaty zagalnonatsionalnoho doslidzhennia. [Health Index. Ukraine - 2019: Results of a national survey]. Kyiv. Retrieved from: http://health-index.com.ua/HI_Report_2019_Preview.pdf [in Ukrainian]. 7. (2018). Tselevyie orientiry i indikatory dlia politiki Zdorovie-2020. Versia 4. [Targets and indicators for Health 2020. Version 4]. Kopengagen: Evropeyskoe regionalnoe byuro VOZ. - www.euro.who.int. - Retrieved from: https://www.euro. who.int/_data/assets/pdf_file/0010/378946/Targets4_RU_WEB.pdf [in Russian].

8. (2014). Monitoring progressa v obespechenii vseobschego ohvata uslugami zdravoohraneniya na urovne otdelnyih stran i na globalnom urovne. Sistema, pokazateli i tseli [Monitoring progress towards universal health coverage at country and global levels Framework, measures and targets]. World Health Organization and International Bank for Reconstruction and Development. - Retrieved from: https://apps.who.int/iris/bitstream/handle/10665/112824/WHO_HIS_HIA_14.1_rus. pdf?sequence=8 [in Russian].

9. (2020). Otchet o hode realizatsii Plana deystviy v podderzhki ispolzovania fakticheskih dannyh, informatsii i nauchnyih issledovaniy pri vyirabotke politiki v Evropeyskom regione VOZ [Progress report on the implementation of the Action Plan to Strengthen the Use of Evidence, Information and Research for Policy-making in the WHO European Region]. Kopengagen, Daniya, Virtualnaya sessiya, 14-15 sentyabrya 2020 g. - www.euro.who.int. - Retrieved from : https://www. euro.who.int/_data/assets/pdf_file/0005/315482/66wd12r_EIPActionPlan_160528.pdf [in Russian].

10. (2019). «Pro zatverdzhennya Planu zahodiv z realizatsii novoho etapu reformuvannia mistsevoho samovryaduvannia ta teritorlalnoii organlzatsii vlady v Ukraini na 2019-2021 roky». Rozporyadzhennya KMU vid 23.01.2019 \# 77-r. ["On approval of the Action Plan for the implementation of a new stage of reforming local self-government and territorial organization of power in Ukraine for 2019-2021". Order of the CMU dated 23.01.2019 No. 77-r.]. - zakon.rada.gov.ua. Retrieved from: https://zakon.rada.gov.ua/laws/show/77-2019-r\#Text [in Ukrainian].

11. (2014). «Pro shvalennia Kontseptsii reformuvannia mlstsevogo samovryaduvannia ta teritorlalnoii organizatsii vlady v Ukraini»». Rozporyadzhennia KMU vid 01.04. 2014 r. \# 333-r ["On approval of the Concept of reforming local selfgovernment and territorial organization of power in Ukraine" : order of the CMU of 01.04.2014 № 333-r]. - zakon.rada.gov. ua. - Retrieved from: https://zakon.rada.gov.ua/laws/show/333-2014-r\#Text [in Ukrainian].

12. Sobolieva, N., \& Chepurko, G. (2017). Samootsinka stanu zdorovia naselenniam Ukrainy [Self-evaluation of health status of the population of Ukraine]. Sotsialni vymiry suspilstva - Social Dimensions of Society, 9 (20), $382-399$ [in Ukrainian].

13. Slabkiy, G.O., Mironyuk, I.S., Brich, V.V., \& Bilak-Lukianchuk, V.Y. (2020). Metodologiya vprovadzhennya systemy gromadskogo zdorovia na rivni obiednanyh teritorlalnyh gromad [Metodology of implementation of the public health system at the level of united territotial communities]. Visnyk sotsialnoyi hihieny ta organizatsyi okhorony zdorovia Ukrainy - Bulletin of Social Hygiene and Health Protection Organization of Ukraine, 3 (85), 62-66 [in Ukrainian].

14. Slabkiy, G.O., Mironyuk, I.S., Koshelia, I I., \& Dudnik, S.V. (2019). Mediko-demografichna situatsiia iak globalna problema gromadskogo zdorovia Ukrainy [Medical-geographic situation as a global problem of public health of Ukraine]. Visnyk sotsialnoyi gigieny ta organizatsyi okhorony zdorovia Ukrainy - Bulletin of Social Hygiene and Health Protection Organization of Ukraine. 3 (81), 62-72 [in Ukrainian].

15. (2020). Pro Tsili staloho rozvytku Ukrainy na period do 2030 roku. Ukaz Prezydenta Ukrainy vid 30 veresnia 2019 roku No722/2019 [On the Goals of sustainable development of Ukraine for the period up to 2030. Decree of the President of Ukraine of September 30, 2019 No. 722]. Prezydent Ukrainy. - www.president.gov.ua. - Retrieved from: https://www. president.gov.ua/documents/7222019-29825 [in Ukrainian].

16. (2018). Tselevyie orientiry i indikatory dlia politiki Zdorovie-2020. Versia 4. [Targets and indicators for Health 2020. Version 4]. Kopengagen: Evropeyskoe regionalnoe byuro VOZ. - www.euro.who.int. - Retrieved from: https://www.euro. who.int/_data/assets/pdf file/0010/378946/Targets4_RU_WEB.pdf [in Russian].

17. (2018). Schorichna dopovid pro stan zdorovia naselennia, sanitarno-epidemichnu situatsiiu ta rezultaty diialnosti sistemy okhoroni zdorovia Ukrainy. 2017 rik [Annual report of the state of health of the population, the sanitary-epidemic situation and the results of activity of the health care system of Ukraine. 2017]. MOZ Ukrainy, DU «UISD MOZ Ukrainy»Ministry of Health of Ukraine, State Institution "WISD Ministry of Health of Ukraine", Kyiv [in Ukrainian].

18. (2003). European Advisory Committee on Health Research (EACHR). Considerations in defining evidence for public health. International Journal of Technology Assessment in Health Care, 19 (3), 559-573.

19. Euro Health Consumer Index. Retrieved from: http://www.healthpowerhouse.com/en/news/euro-health-consumerindex-2015/. 
20. (2018). Strengthening national health research systems (NHRS) in the WHO European Region: implementation of the European Action Plan to strengthen the use of evidence, information and research for policy-making in Ukraine. Summary of the national meeting on research for health, 17-19 October 2018, Kiev, Ukraine. Copenhagen: WHO Regional Office for Europe. - Retrieved from: https://www.euro.who.int/_data/assets/pdf_file/0004/388912/nhrs-ukr-eng.pdf.

21. (2020). Towards a culture of evidence-informed policy. Report of the 6th EVIPNet Europe multicountry meeting, 3-5 September 2019, Istanbul, Turkey. Copenhagen. - Retrieved from: https://www.euro.who.int/_data/assets/pdf_ file/0004/426784/MeeetingReport_EN_WHO_7proof.pdf.

\section{INFORMATION AND INSTITUTIONAL RESOURCES OF PUBLIC POLICY FORMATION IN HEALTHCARE OF UKRAINE}

P. M. Mykhailenko, Yu. M. Skaletsky, S. V. Protas

State Institution "O. Marzeiev Institute for Public Health of the National Academy of Medical Sciences of Ukraine», Kyiv, Ukraine

Purpose: to determine the available institutional and information resources to provide information and analytical support for the formation and implementation of state policy in the field of health care in Ukraine and ways to intensify their interaction.

Materials and Methods. International and national regulations, analytical and guiding documents of the WHO Regional Office for Europe, reporting and analytical reports of central executive bodies, independent experts, statutory documents of institutions involved in the creation and processing of scientific and factual data, collection and analysis of statistics in the field health care, scientific publications. The bibliosemantic method of research is applied.

Results. Guidelines and analytical documents of the WHO Regional Office for Europe on information and analytical support of policy decision-making were analyzed; institutional resources and sources of relevant information to ensure decision-making in the formation and implementation of public policy are studied. In particular, it is noted that state institutions of the National Academy of Medical Sciences of Ukraine, as the administrator of scientific data and evidence in the field of health, is the main institutional resource of information and analytical decision support and should perform a coordinating function in its provision.

Conclusions are aimed at ensuring effective interaction of all stakeholders who manage relevant information, ensuring regular summarization and disclosure of information in the field of health care and presentation of information and analytical work to policy makers and the general public.

KEY WORDS: policy formation and implementation; evidence-informed policy-making; data and evidence; health care system; institutional resources for decision making.

\section{Відомості про авторів:}

Рукопис надійшов до редакції 25.06.2021 p.

Михайленко Поліна Михайлівна - кандидат біологічних наук, старший науковий співробітник лабораторії безпекових стратегій в охороні здоров'я дУ «Інститут громадського здоров'я ім. О. М. Марзєєва НАМН України»; тел.: +38(044) 292-06-03.

Скалецький Юрій Миколайович - доктор медичних наук, професор, завідувач лабораторії безпекових стратегій в охороні здоров'я ДУ «Інститут громадського здоров'я ім. О. М. Марзєєва НАМН України»; тел.: +38(044) 292-06-03.

Протас Святослав Вікторович - кандидат медичних наук, старший науковий співробітник лабораторії безпекових стратегій в охороні здоров'я ДУ «Інститут громадського здоров'я ім. О. М. Марзєєва НАМН України»; тел.: +38(044) 292-14-23. 